Evgeniya G. Radygina

\title{
Marketing relations in online advertising
}

\section{KEYWORDS}

communication;

marketing communication;

marketing relationships;

customer communications;

internet;

social media

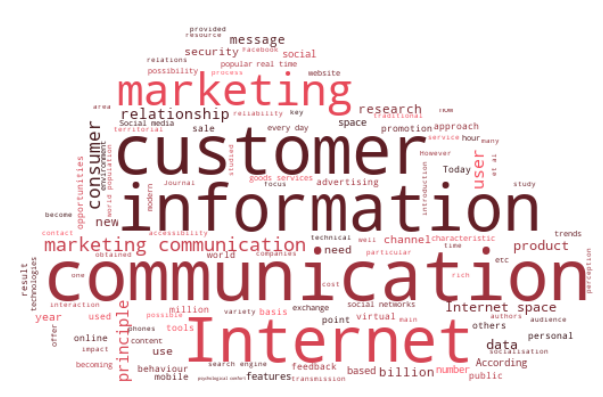

Word Cloud Generated by:

https://wordscloud.pythonanywhere.com/

\section{ABSTRACT}

Introduction. The relevance of the research is due to the fact that the model of communication between customers and suppliers within the online space has long influenced all marketing stages in the introduction of goods and services, starting with customer awareness, attitudes towards customers, soliciting potential customers to testing new products, sales, and customer retention. The purpose of the research is to identify features of the Internet as a space of marketing relationships and formulate the principles of interaction with users.

Materials and methods. The reviewed sources included contemporary periodicals: Journal of Targeting Measurement and Analysis for Marketing, Electronic Markets, Marketing, etc. The study of Internet resources was based on the authors' own data received by analysing the portals WebCanape, WebsiteSetup, Statista, etc.

Results. There are nearly half a billion new users on social media; trillions of dollars have been spent in online stores, according to the annual Global Digital 2021 report. As of October 2021, the most popular social networks in the world by the number of active users (in millions) are Facebook $(2,894)$, YouTube $(2,291)$, WhatsApp $(2,000)$, Instagram $(1,393)$, Facebook Messenger $(1,300)$, Weixin/ WeChat $(1,251)$, TikTok $(1,000)$, etc.

The Internet as a new business environment differs from traditional economic sectors by a higher level of heterogeneity. From the standpoint of marketing, the Internet makes it possible to simultaneously bring a message to a large number of users (mass communication is ensured), on the other hand, to customise the offer for specific consumers according to their needs.

Conclusion. Contemporary marketing follows the consumer, i.e. uses the online environment as a point of contact with the consumer to promote and distribute products. Relationship marketing theories are based on the need for companies to invest in relationships between themselves and consumers. Relationship marketing focuses on taking relationships between the company and the consumer from a state of engagement to that of loyalty. Each customer has a personality and his/her relationship with a particular brand becomes the dominant factor influencing his/her decision regarding purchase or service.

Radygina, E. G. (2021). Marketing relations in online advertising. Economic consultant, 36 (4), 33-41. doi: 10.46224/ecoc.2021.4.4 


\section{INTRODUCTION}

Communication plays a vital role in all areas of life in today's society. The content of the term "communication" is studied by philosophers, sociologists, educators, psychologists, and marketers. Communication is an active interaction between actors or process owners involving the exchange of information. The basis for communication is provided by the transmission of a message, on the basis of which relations are subsequently built, a behavioural strategy in society. Communication also has a significant impact on the socialisation of an individual, the promotion of values and attitudes, standards of behaviour, personal identity, professional competence; also, the functions of reflection and social control are realised through communication.

Marketing communications are an information-rich area, since the interaction between consumers and producers in a market economy is associated with information sharing [1].

Marketing communications is the conveyance of information about a product (service) to the target audience. In this case, advertising, personal sales, direct marketing, sponsorship, public relations, etc. are used as marketing communications tools. Information flows include the range, characteristics of goods and services, consumers' personal details, financial flows, etc. The customer-oriented approach expanding the marketing opportunities of e-commerce is becoming increasingly popular [2].

However, it is becoming insufficient to use the listed tools. The key problems that need to be addressed are: 1) the impossibility of organising effective customer communications in real time, and 2) the need to customise offers for a particular consumer. Today's marketing communications are becoming more information-rich and high-tech and require new technology concepts. The main one is the Internet space promotion.

The model of communication between customers and suppliers within the Internet space has long influenced all marketing stages of the introduction of goods and services, from customer awareness, attitudes towards customers, attracting potential customers to testing new products, sales, and customer retention [3]. From the onset, Internet marketing has mainly concerned the information dissemination through websites and email newsletters, advertising on both search and marketplaces, measuring customer activity and communicating customer feedback. Today, this is still true as the convergence of many technologies has expanded the power of online marketing towards more sales and service delivery opportunities in real time.

The purpose of the research is to identify features of the Internet as a space of marketing relationships and formulate customer communications principles. 


\section{RESEARCH MATERIALS AND METHODS}

During the research into the essence and content of marketing communications in the Internet space, the authors used the research materials by Anderson-Butcher et al. [4], Tomse and Snoj [5], Plaksin, Abdrakhmanova, Kovaleva, and others. Features of information perception and building relationships with consumers were studied based on the works by Dickson et al. [6], Wright and Hinson [7], and others.

The research into Internet resources was based on the study of data obtained by companies collecting and indexing public messages and hashtags on the Internet (Rusability [8], Brand Analytics [9], Infographics [10], Yandex [11]), data from their own research portals (WebCanape [13], WebsiteSetup [16], Statista [17; 18]).

The analysed sources included modern periodicals: Journal of Targeting Measurement and Analysis for Marketing, Electronic Markets, Marketing, The Cornell Hotel and Restaurant Administration Quarterly, Public Relations Journal, Journal of Database Marketing \& Customer Strategy Management, etc.

The key term in the theory of marketing communications is "information" considered as "a message transmitted through communication channels" from the point of view of the functional approach (Shannon, Kanygin, Yaglom); as "content, internal characteristic of an object or process" from the standpoint of the attributive approach (Viner, Korogodin, E. Schroedinger); "the meaning, content of messages received by a person from the outside world through his/ her senses" from the point of view of the anthropological approach [12]. Thus, the essence of marketing communication is the information exchange between marketing subjects (consumer, manufacturer and intermediaries) which contributes to the emergence of an impression from the consumer that influences consumer behaviour.

\section{RESULTS}

During marketing communication, the focus is on the quality of information relationships which are reflected in the accuracy, reliability, security, and relevance of information. The Internet is a special communication space in which new structural relationships and communication connections are generated.

The Internet is becoming a space for social engagement, the creation of values-based orientations, the transmission and interiorisation of sociocultural experiences. According to the annual Global Digital 2021 report, there are almost half a billion new users on social networks, 1.3 billion years were spent on the Internet last year, trillions of dollars were spent in online stores.

Mobile devices: Today, 5.22 billion people use mobile phones, 66.6\% of the world's population. Since January 2020, the number of unique mobile users has grown by $1.8 \%$ (93 
million), while the total number of mobile connections has increased by 72 million $(0.9 \%)$ and reached 8.02 billion by early 2021 .

Internet: In January 2021, 4.66 billion people worldwide used the Internet, up 316 million $(7.3 \%)$ from last year. The Internet penetration rate is now 59.5\%. However, COVID-19 has had a significant impact on the collection of data on the number of Internet users, so the actual numbers may be higher.

Social media: There are now 4.20 billion social media users in the world. Over the past 12 months, this figure has grown by 490 million representing an increase of more than $13 \%$ on a year-to-year basis. Social networks in 2021 are used by $53.6 \%$ of the world's population.

Two-thirds of the world's population use mobile phones every day. At the same time, according to App Annie, Android users now spend more than 4 hours a day on their phones [13].

According to research by Viktorova Batkaeva, the main purpose of visiting the Internet is communication for $95 \%$ of respondents aged 14 to 30 years. At the same time, 57\% of respondents go online every day and spend 2 to 4 hours on it, 37\% - more than 4 hours every day, $6 \%$ - one hour or less [14, p. 92].

Social media are the most popular communication channels, which can be defined as "a variety of activities for the creation and exchange of information, in which many actors are involved via the Internet" [15, p. 33]. The main channels of communication in the Internet space include sites, search engines, review portals, video channels, articles and publications in the media, contextual advertising, social networks.

As of 2021, according to WebSiteSetup, there were over 1.7 billion websites worldwide. Approximately 576,000 new sites appear every day [16].

According to Statista, the most popular websites in the world as of June 2021 by total visits (in billions) were Google.com (86.9), YouTube.com (22.8), Facebook.com (20), Wikipedia.org (13.6), and others [17].

The most popular social networks in the world as of October 2021 by the number of active users (in millions) were Facebook (2,894), YouTube $(2,291)$, WhatsApp $(2,000)$, Instagram (1,393), Facebook Messenger (1,300), Weixin/WeChat (1,251), TikTok (1,000), and others [18].

The structure and characteristics of the audience, as well as the properties of information transmission channels, determine the characteristics of the Internet as a marketing communications space (see Table 1).

Table 1

Marketing communications features in the Internet space

\begin{tabular}{|l|l|}
\hline \multicolumn{1}{|c|}{ Opportunities } & \multicolumn{1}{c|}{ Threats } \\
\hline Low resource cost & Complex result predictability \\
\hline Reliability of contact & Search engine addiction \\
\hline Psychological comfort for the consumer & Non-transparent pricing \\
\hline Feedback capability & Quick return impossible \\
\hline Flexible marketing policy & Limited target group \\
\hline Possibility to pay for goods/services & Product virtuality \\
\hline Automatic accounting of information & Ensuring data security \\
\hline
\end{tabular}


The Internet as a new business environment differs from traditional economic sectors by a higher level of heterogeneity. From the standpoint of marketing, the Internet makes itn possible to simultaneously bring a message to a large number of consumers (mass communication is ensured); on the other hand, to customise an offer for specific consumers according to their needs. A rich figurative and semantic environment and emotionally coloured virtual communication create the basis for obtaining impressions that are normally not realised by users. At the same time, exciting topics evoke more emotions if the user is directly involved in the discussion of them.

Internet communication has a tremendous advantage for users in comparison with real communication: psychological comfort provided by territorial remoteness, if necessary, a temporary delay, the possibility of anonymity, allowing the implementation of psychological and social statuses and roles inaccessible in reality [4]. Virtual communication incorporated in the modern socialisation set-up freely competes with real communication within the framework of traditional social institutions. Social and psychological studies of the impact of the Internet on a person indicate that during cyber socialisation, mental processes, including emotional and motivational ones, are qualitatively transformed, consciousness and behaviour are transformed [19].

The promotion of information technologies and virtual communication tools makes it possible to highlight the key trends in the development of the Internet as a marketing communication space:

1) An increase in the intensity of communicative exchange (due to the introduction of new information and communication technologies, any online activity begins to focus on the social interaction);

2) Change in the form of a message (both verbal and visual components of the message, symbolic representation, a kind of coding system, additional visual components, emoji and emoticons meet);

3) Change in the perception of the text (the line between public and private messages dissolves, written speech becomes similar to oral speech, the information selection mechanism is turned on);

4) Borders and barriers are being erased (linguistic, spatial, temporal, between publicity and private life).

The customer communication principles in the Internet space allow combining the selected features and trends in the promotion of communication:

- the principle of territorial accessibility (communications are carried out irrespective of the user location);

- the principle of information accessibility (information is provided in an accessible form and is of a public nature, the accuracy and completeness of information can be easily verified);

- the principle of individualisation (a custom approach in determining customer needs and expectations and the preparation of offers, the recognition of cultural differences); 
- the principle of feedback (study of customer satisfaction through the use of various communication channels);

- the principle of interactivity (customer communications take place in real time with a variety of software and hardware);

- the principle of technical security (it is necessary to provide technical conditions for using the Internet);

- the principle of security and personal data protection.

\section{DISCUSSION}

Over the past twenty years, it has become abundantly clear that the Internet is not a fad but a basis for relationship marketing [20].

It should be noted that research on observing consumer behaviour in real time in order to study their purchasing behaviour based on clicks and other indicators [21], as well as customer emotion analysis as strategic variables for promotion of customer involvement, are of particular interest [22].

The authors agree with Jara et al. that social media marketing expands the ability to identify products with new technologies, which allows for enhanced product information [23].

The obtained results are consistent with Subramaniam's findings that the use of web ads, virtual stores, and virtual communities provides marketers with innovative opportunities to communicate with customers, understand their preferences and personalise marketing offers at a much lower cost and much more efficiently than with traditional tools [24].

Modern marketing follows customers, or uses the online environment as a point of contact with the customer to promote and distribute products. Now, many companies work with users, define their needs, and then create products taking into account their requirements. Technology has brought analytical tools, sales automation, and data mining capabilities to entities that process consumer data and synchronise their strategies based on consumer profiles, segments and expectations.

The relationship marketing theory is based on the need for companies to invest in relationships between themselves and customers. Relationship marketing focuses on moving the relationships between the company and the customer from a state of engagement to a state of loyalty.

As Jackson and Ahuja rightly point out, it would be nice for managers to adopt a customercentric marketing paradigm, i.e. on customer's personality, perception and participation. The authors attribute this to the fact that today's customers have great rights and opportunities, they own the Internet, have wider access to information in the digital world and are the area of focus of entities in a highly competitive environment [25].

The modern shopper has a wide variety of choices and relies heavily on peer reviews, website information, Internet searches, and comparison of product specifications and prices. 
Each customer has a personality and his/her relationship with a particular brand becomes the dominant factor influencing his/her decision on purchase or service.

\section{CONCLUSION}

The Internet as a marketing communication space has features that characterise the possibilities of using it (low cost of resources, reliability of contact, psychological comfort for customers, the possibility of feedback, flexible marketing policy, the possibility of paying for goods/services, automatic accounting of information), allowing you to quickly achieve your goals with greater efficiency; as well as threats that need to be addressed (complex result predictability, dependence on search engines, non-transparent pricing, the impossibility of a quick return, limited audience, product virtuality and data security).

The studied features and trends in the development of the Internet space made it possible to formulate the customer communications principles: territorial and information accessibility, individualisation, feedback, interactivity, technical security, security and protection of personal data. The results obtained indicate that the formation of this marketing communications space has not yet ended and demonstrates certain trends. However, the use of only the Internet space in marketing communications does not fully achieve all marketing goals, and this communication channel should be used along with others (mass media, outdoor advertising; exhibition marketing; advertising events, communications at points of sale, etc.).

\section{REFERENCES}

1. Low, G.S., \& Mohr, J.J. (2001). Factors affecting the use of information in the evaluation of marketing communications productivity. Journal of the Academy of Marketing Science, 29, 70. DOI: 10.1177/0092070301291005

2. Tsiotsou, R., Rigopoulou, I., \& Kehagias, J. (2010). Tracing customer orientation and marketing capabilities through retailers' websites: A strategic approach to internet marketing. J Target Meas Anal Mark, 18, 79-94. DOI: 10.1057/jt.2010.5

3. Alt, R., \& Osterle, H. (2013). Electronic Markets on Internet marketing. Electron Markets 23, 173-174. DOI: 10.1007/s12525-013-0140-8

4. Anderson-Butcher, D., Ball, A., Brzozowski, M., Lasseigne, A., Lehnert, M., \& McCormick, B. L. (2010). Adolescent weblog use: Risky or protective? Child Adolescent Social Work Journal, 27(1), 63-77.

5. Tomse, D., \& Snoj, B. (2014). Marketing communication on social networks: Solution in the times of crisis. Marketing, 45(2), 131-138.

6. Dickson, D., Ford, R.C., \& Laval, B. (2005). Managing real and virtual waits in hospitality and service organizations. The Cornell Hotel and Restaurant Administration Quarterly 
46(1), 52-68.

7. Wright, D. K., \& Hinson, M. D. (2009). Examining how public relations practitioners actually are using social media. Public Relations Journal, 3(3), 173-181.

8. Analytics of Russian Giants: VKontakte and Odnoklassniki. Infographics. Available at: https://rusability.ru/internet-marketing/smm/analitika-rossijskih-gigantov-vkontakte-iodnoklassniki-infografika/ (accessed on 20 November 2021).

9. Sokolova, N. Social Networks in Russia: Figures and Trends, Autumn 2018. Available at: https://br-analytics.ru/blog/socseti-v-rossii-osen-2018/ (accessed on 20 November 2021).

10. The Most Visited Sites in Russia / Infographics.ru. Visual Analytics of the Modern World. Available at: https://infografics.ru/all/samye-poseshhaemye-sajty-rossii/ (accessed on 20 November 2021).

11. Research. Runet Content. Available at: https://yandex.ru/company/researches/2009/ya_ content_09 (accessed on 20 November 2021).

12. Fridland A.Ya. Information: An Overview of Modern Ideas about the Definition Essence and Concepts. Federal portal "Educational One-Stop Shop". Available at: http://window. edu.ru/catalog/pdf2txt/804/58804/28666?p_page=3. (accessed on 23 November 2021).

13. All Statistics of the Internet and Social Networks for 2021 - Figures and Trends in the World and Russia/WebCanape. Available at: https://www.web-canape.ru/business/vsyastatistika-interneta-i-socsetej-na-2021-god-cifry-i-trendy-v-mire-i-v-rossii/ (accessed on 20 November 2021)

14. Viktorova, E. V., \& Batkaeva, E. R. (2017). Impression as a component and factor of socialisation in the communicative space of the Internet. Communicology, 5(1), 88-98.

15.Surova, E. E., \& Vasilyeva, M. A. (2017). Influence of the Internet environment on representation and identification strategies. International Research Journal, 3-1 (57), 97-99.

16. WebsiteSetup.org: How to Make a Website. Available at: https://websitesetup.org/news/ how-many-websites-are-there/ (accessed on 20 November 2021)

17. Statista. Available at: https://www.statista.com/statistics/1201880/most-visited-websitesworldwide/ (accessed on 20 November 2021)

18. Statista. Available at: https:/www.statista.com/statistics/272014/global-social-networksranked-by-number-of-users/ (accessed on 20 November 2021)

19. Pleshakov V.A. (2012). Cybersocialization of the person: from Homo Sapiens to Homo Cyberus. Moscow, 212.

20. Allan, S., \& Chudry, F. (2000). The Internet - A fad or a fundamental for relationship marketing. J Database Mark Cust Strategy Manag, 8, 73-86. DOI: 10.1057/palgrave. jdm.3240020

21. Corley, J. K., Jourdan, Z., \& Ingram, W. R. (2013). Internet marketing: a content analysis of the research. Electron Markets, 23, 177-204. DOI: 10.1007/s12525-012-0118-y

22. Sinha, N., Ahuja, V., \& Medury, Y. (2011). Corporate blogs and Internet marketing - 
Using consumer knowledge and emotion as strategic variables to develop consumer engagement. J Database Mark Cust Strategy Manag, 18, 185-199. DOI: 10.1057/ dbm.2011.24

23. Jara, A. J., Parra, M. C., \& Skarmeta, A. F. (2014). Participative marketing: extending social media marketing through the identification and interaction capabilities from the Internet of things. Pers Ubiquit Comput, 18, 997-1011. DOI: 10.1007/s00779-0130714-7

24. Subramaniam, C., Shaw, M. J., \& Gardner, D. M. (2000). Product marketing and channel management in electronic commerce. Information Systems Frontiers, 1, 363-378. DOI: 10.1023/A:1010061924822

25. Jackson, G., \& Ahuja, V. (2016). Dawn of the digital age and the evolution of the marketing mix. J Direct Data Digit Mark Pract, 17, 170-186. DOI: 10.1057/dddmp.2016.3

26. Slivar, I., \& Krizman Pavlovic, D. (2012). Internet marketing communication of tourist destinations: review of DMO websites in Europe. Economic Research-Ekonomska Istrazivanja, 25, sup2, 173-186. DOI: 10.1080/1331677X.2012.11517581

27. Peterson, R. A., Balasubramanian, S., \& Bronnenberg, B. J. (1997). Exploring the implications of the internet for consumer marketing. J of the Acad Mark Sci, 25, 329. DOI: 10.1177/0092070397254005

28. Varadarajan, P. R., \& Yadav, M.S. (2002). Marketing strategy and the internet: An organizing framework. J of the Acad Mark Sci, 30, 296-312. DOI: 10.1177/009207002236907

29. Proenca, J., Silva, M., \& Fernandes, T. (2010). The impact of the Internet upon bank marketing. J Financ Serv Mark, 15, 160-175. DOI: 10.1057/fsm.2010.12

\section{INFORMATION ABOUT THE AUTHOR}

Evgeniya G. Radygina (Russian Federation, Yekaterinburg) - Associate Professor, PhD in Pedagogical Sciences, Associate Professor at the Department of Tourism Business and Hospitality. Ural State University of Economics. E-mail: radygina@bk.ru. ORCID ID: 00000002-2233-7734. ResearcherID: AAD-2605-2019

\section{(c) (1) () \\ open 2 Access}

Available: https://statecounsellor.wordpress.com/2021/11/28/radygina-2/

Received: Mar 2, 2021 | Accepted: Sep 24, 2021 | Published: Dec 1, 2021

Editor: Norlaile S. Hudin, PhD (Management). Universiti Pendidikan Sultan Idris, MALAYSIA

Copyright: ( 2021 Radygina, G. This is an open access article distributed under the terms of the Creative Commons Attribution License, which permits unrestricted use, distribution, and reproduction in any medium, provided the original author and source are credited.

Competing interests: The authors have declared that no competing interests exist. 